UDC 141.3

LBC 87.6

\title{
PUBLIC SPHERE, VIRTUALIZATION, RHIZOME: COMMUNICATIVE PRACTICES OF RUNET SOCIAL MEDIA
}

\author{
Aleksandr V. Mlechko \\ Volgograd State University, Volgograd, Russian Federation \\ Ivan N. Shamaev \\ Volgograd State University, Volgograd, Russian Federation \\ Olga N. Didenko \\ Volgograd State University, Volgograd, Russian Federation \\ Olesja A. Kozlova \\ Volgograd State University, Volgograd, Russian Federation
}

\begin{abstract}
In the present work, the interrelation of social media with the philosophical thought of poststructuralism is investigated. The nature of the manifestation of this connection, the reasons for its actualization, the main one being the crisis of confidence in traditional media, is largely related to poststructuralist world outlook and attitude.

Particular attention is paid to the structure of social media, the emphasis is on their nonlinearity. The image of the rhizome, described by J. Deleuze and F. Guattari, helps to reveal the peculiarities of the text functioning within the social media space and the formation of an interpretative-commentary complex around it.The latter is capable of changing the initial intentions in many ways, and here correlation with the poststructuralist idea of the "death of the author" is traced. Semantic dominants of this non-linear system are associated both with public expectations and with the activities of certain political actors and business structures. As a result, the interpretative-commentary complex acquires the features of a poly-subject, affecting the subject-object dichotomy, which underlies the classical models of communication.

The relationship of social media with the philosophical thought of poststructuralism is also studied in the context of the public sphereideas. Modern interactive media are distinguished by the interpenetration of collective social and individual personal beginnings: the topics that the public and certain social groups consider most relevant are revealed here. In addition, a large number of interpretations are allowed. At the same time, the discussion is mainly limited to the presentation of certain views without establishing common ground, so we cannot yet talk about the space of the classical public sphere.

Separately, the issue of increasing image symbols within the communicative space of social media is raised, it is considered in the context of the theory of simulacra by J. Baudrillard. Social media simultaneously acts as a product of the virtual environment, and as a reaction to it, where network activity correlates with other types of activity. In the present work, a conclusion about the complex nature of relationship between social media and modern philosophical thought is made. A systematic study of constructs that have an impact on the communicative practices of social media provides the most objective ideas about this phenomenon.
\end{abstract}

Key words: virtualization, poststructuralism, public sphere, rhizome, social media.

УДК 141.3

ББК 87.6

\section{ПУБЛИЧНАЯ СФЕРА, ВИРТУАЛИЗАЦИЯ, РИЗОМА: КОММУНИКАТИВНЫЕ ПРАКТИКИ СОЦИАЛЬНЫХ МЕДИА РУНЕТА}

\author{
Александр Владимирович Млечко
}

Волгоградский государственный университет, г. Волгоград, Российская Федерация 
Публичная сфера, виртуализация, ризома: коммуникативные практики социальных медиа Рунета

Иван Николаевич Шамаев

Волгоградский государственный университет, г. Волгоград, Российская Федерация

Ольга Николаевна Диденко

Волгоградский государственный университет, г. Волгоград, Российская Федерация

\section{Олеся Александровна Козлова}

Волгоградский государственный университет, г. Волгоград, Российская Федерация

Аннотация. В представленной работе исследуются взаимосвязь социальных медиа с философской мыслью постструктурализма, характер проявления этой связи, причины ее актуализации, главной из которых является кризис доверия к традиционным СМИ, во многом связанный с постструктуралистским миропониманием и мироощущением.

Особое внимание уделяется структуре социальных медиа, акцент делается на их нелинейности. Образ ризомы, о котором писали Ж. Делез и Ф. Гваттари, помогает раскрыть особенности функционирования текста внугри пространства социальных медиа и формирования вокруг него трактовочно-комментарийного комплекса. Последний во многом способен изменять изначальные интенции, в чем прослеживается корреляция с постструктуралистской идеей «смерти автора». Семантические доминанты в этой нелинейной системе связаны как с общественными ожиданиями, так и с деятельностью определенных политических акторов и бизнесструктур. В итоге трактовочно-комментарийный комплекс приобретает черты полисубъектности, влияя на субъект-объектную дихотомию, которая лежит в основе классических моделей коммуникации.

Также взаимосвязь социальных медиа с философской мыслью постструктурализма изучается в контексте представлений о публичной сфере. Современные интерактивные медиа отличаются взаимопроникновением коллективно-общественного и индивидуально-личностного начал: здесь раскрываются темы, которые считают наиболее актуальными сама общественность и определенные социальные группы. Кроме того, допускается сколь угодно большое количество интерпретаций. Вместе с тем дискуссия в основном ограничивается презентацией тех или иных взглядов без установления точек соприкосновения, что не позволяет говорить о пространстве классической публичной сферы.

Отдельно поднимается вопрос увеличения имиджевых символов внутри коммуникативного пространства социальных медиа, он рассматривается в контексте теории симулякров Ж. Бодрийяра. Социальные медиа одновременно выступают и как порождение виртуальной среды, и как реакция на нее, где сетевая деятельность коррелирует с иными видами активности.

В представленной работе делается вывод о сложном характере взаимосвязи социальных медиа и современной философской мысли. Системное исследование конструктов, имеющих влияние на коммуникативные практики социальных медиа, обеспечивает максимально объективные представления об этом феномене.

Ключевые слова: виртуализация, постструктурализм, публичная сфера, ризома, социальные медиа.

Магистральное направление научных работ, посвященных становлению и развитию коммуникативных практик Рунета как системы и социальных медиа как его части, непосредственно связано с технологическими детерминантами,сделавшими возможной мгновенную передачу информации, ее ретрансляцию и т. д. Иные причины, оказавшие немаловажное влияние на указанный объект изучения, оказываются в этом случае либо освещенными в недостаточной степени, либо игнорируются вовсе.

При этом комплекс факторов, связанных с историческим развитием медиасферы Рунета, представляется куда шире: он включает контекст, в который входит ряд культур- но-исторических предпосылок, а также экономические и политические факторы (влияние последних увеличивается на данном этапе развития изучаемой системы). В силу развития системы социальных медиа усиливается и обратная тенденция: они оказываются способными влиять на социальные институты как посредством взаимосвязи с традиционными средствами массовой информации, так и напрямую.

Особую значимость для получения максимально объективного - со всеми возможными оговорками - представления о новых коммуникативных практиках социальных медиа Рунета имеет изучение их корреляции с постструктуралистской философской мыслью 
и постмодернистской культурой в целом, что, разумеется, предполагает включение указанных феноменов в общий философский контекст.

Эта проблематика находилась в центре внимания отечественных исследователей в эпоху становления Рунета и его массовизации. Так, российский ученый Н.В. Громыко еще в 2002 г. отмечал: «Интернет - это квинтэссенция постмодернистского строя и стиля жизни, это то пространство, где постмодернизм представлен наиболее развернуто и по форме наиболее адекватно: войдя в Интернет, погружаешься в суть постмодернистской эпохи во всей ее философско-миров оззренческой и антропологической специфике» [3, с. 176].

В дальнейшем, однако, акценты при изучении новых коммуникативных практик Рунета, в том числе связанных с новыми медиа в различных формах, смещаются в сторону установления их места относительно традиционных, проходя эволюционный путь от оппозиционности к симбиозу. Вопросы взаимосвязи с постструктуралистской философской мыслью оказываются малоизученными. Образуется лакуна, заполнение которой представляется значимым в контексте работ, посвященных специфике новых медиа, а также в научных трудах междисциплинарного характера.

Появление социальных медиа Рунета во многом связано с кризисом доверия к традиционным средствам массовой информации, их ангажированностью и зависимостью от властных структур и бизнес-сообщества. Отечественный исследователь Д.В. Иванов в работе «Виртуализация общества» пишет: «Симптомами упадка институтов можно считать активизацию так называемых новых социальных движений на фоне инертности масс, и в целом - фрагментацию социального порядка» [6, с. 38].

В условиях информационного общества, во многом связанного с постструктуралистским мироощущением, самоочевидным становится вопрос об альтернативных источниках сведений. Оппозиционные СМИ различного толка отчасти выполняют указанные функции, однако в силу своей институционализации (по сути они так же связаны с политическими и экономическими группами) не покрывают аудиторные потребности.
Таким образом, одновременно с технологическими возможностями возникает социальный запрос на продуцирование и обработку контента самими пользователями, которые, впрочем, также являются представителями некоторых социальных групп и носителями определенных идеологически окрашенных ценностей. В этих условиях неизбежно увеличивается число оценок и трактовок фактов. СМИ претендуют на объективное отражение социальной реальности, в то время как в социальных медиа наиболее ярко являет себя процесс поиска постоянно ускользающей истины.

Аудиторные ожидания и активность задают рамки идеальной модели функционирования социальных медиа, несоответствующей реальному положению дел, при котором позиции властных структур, политических сил и профессиональных медиа достаточно прочны. Симптоматичным представляется сам социальный запрос на альтернативные источники контента, корреспондирующий с постструктуралистским мироощущением.

Вопрос о границах и возможностях гражданской журналистики оставался одним из центральных при изучении новых коммуникативных практик: одни исследователи приписывали изучаемому феномену широкий потенциал и прогнозировали скорое замещение традиционных СМИ, в то время как другие отмечали возникающие в этой связи риски.

Новозеландский исследователь социальных медиа Л. Гуд пишет по этому поводу: «Мы подвергаемся опасности назвать гражданской журналистикой все, что преподносится как альтернатива "мейнстриму” и “традиционной” журналистике. Коннотации инаковости, связанные с концепцией гражданской журналистики, возможно, привлекательны, но здесь следует быть осторожными... Даже в том случае, если независимость от “традиционных” СМИ четко задекларирована и институционально подтверждена, сайты, посвященные гражданской журналистике, могут перенимать (осознанно или нет) их традиции и нормы. Альтернатива, конечно, всегда относительна» [13].

Концепция отличности от традиционных СМИ, принципиальной непохожести на них, связанная с постструктуралистским разочарованием в традиционных социальных институтах, 
Публичная сфера, виртуализация, ризома: коммуникативные практики социальных медиа Рунета

остается значимой характеристикой социальных медиа Рунета, но не является базовым принципом. На данном этапе их изучения акцент делается не на производстве пользовательского контента, но на расширение функциональных границ в деятельности пользователя, долгое время остававшегося исключительно информационным потребителем.

Особое внимание при изучении взаимосвязи философской мысли постструктурализма с социальными медиа Рунета целесообразно уделить такой структурной характеристике последних, как нелинейность и отсутствие централизации, иерархичности, присущей традиционным средствам массовой информации.

В этой связи остро встает вопрос определения путей распространения того или иного текста, его трансформаций в коммуникативной среде, формирования вокруг него трактовочно-комментарийного комплекса, включающего как комментарии, репосты, хэштеги, так и общий контекст ресурсов, в которые он попадает. Первоначальная авторская интенция в этом случае становится точкой для дальнейших трактовок: подобные ситуации можно обнаружить и в литературе, и в журналистских текстах доинтернетовского периода, однако именно на данном этапе развития технологий и социокультурного контекста это явление приобретает массовый характер.

В коммуникативном пространстве социальных медиа сообщение распространяется во многом хаотическим образом: неоднородность и неустановленность границ аудитории возводится в абсолют. В этом контексте целесообразно уделить внимание вышедшей в 1980 г. работе французских философов Ж. Делеза и Ф. Гваттари «Капитализм и шизофрения. Тысяча плато», в которой они вводят в философский дискурс понятие хаотичной корневой структуры - «rhizome» («корневище»), позаимствованное из ботаники [5]. Это структура, состоящая из многочисленных побегов, не связанных между собой простыми линейными отношениями. Обнаружение стержня при этом либо вызывает затруднения, либо вовсе представляется невозможным. Во главе угла стоят «принципы соединения и неоднородности: любая точка ризомы может - и должна быть - присоединена к любой другой ее точке» [4]. Ж. Делез и Ф. Гваттари поясняют: «Главный корень абортирован или почти до конца уничтожен; к нему прививается и обретает чрезвычайное развитие непосредственное и неопределенное множество вторичный корней. На сей раз естественная реальность проявляется в виде выкидыша главного корня, но тем не менее его единство существует как прошлое или грядущее, как возможное» [4].

Подобная структурная особенность напрямую влияет на жизнеспособность системы как таковой: при повреждении и даже уничтожении части «побегов» основная их часть продолжит функционировать в силу хаотичности и децентрализации. Эту особенность исследователи обозначили как принцип «незначащего разрыва»: «Любая ризома включает в себя линии сегментарности, согласно которым она стратифицирована, территоризирована, организована, означена, атрибутирована и т. д.; но также и линии детерриторизации, по которым она непрестанно ускользает» [4].

Сформулированный в качестве иллюстрации нового типа текстов этот постструктуралистский образ вполне применим для описания функционирования системы социальных медиа. Представленная хаотичная корневая структура не может не влиять на классическую субъект-объектную дихотомию, положенную в основу классических моделей коммуникации. Она неизбежно претерпевает значительные изменения. «Мочковатая система на деле не порывает с дуализмом, с взаимодополнительностью субъекта и объекта, с естественной реальностью и духовной реальностью - единство не перестает перечить и противиться объекту, тогда как в субъекте торжествует новый тип единства. Мир утратил свой стержень, субъект не может больше создавать дихотомию, но он достигает более высокого единства - единства амбивалентности и сверхдетерминации - в измерении, всегда дополнительном к измерению собственного объекта» [4].

Несмотря на принципиальную децентрализованность описываемой системы, выступающую в качестве базисного принципа, в ней способны зарождаться, получать распространение и чередоваться различные семантические доминанты. Во многом эти доминанты 
связаны с аудиторными запросами и различными группами, представленными в том или ином сегменте социальных медиа. С общественными ожиданиями сопряжены трансформации текстовых фрагментов в процессе формирования трактовочно-комментарийных комплексов. Опрометчиво было бы элиминировать и влияние традиционных социальных институтов, политических акторов, бизнесструктур, общественных объединений и, конечно же, профессиональных СМИ, переносящих в новое коммуникативное пространство определенную новостную повестку. Таким образом, альтернативное и инаковое оказывается сопряженным с традиционным.

Закономерности, в соответствии с которыми получают распространение и сменяют друг друга семантические доминанты, к которым в данном случае применим образ «побега», опираются на факты самой социальной действительности, выступающие исходной точкой для многочисленных трактовок и интерпретаций, а также на существующие внутренние механизмы развития социальных медиа. Таким образом, в исследовании, посвященном этому феномену, остро стоит вопрос комплексного подхода, который выражается в междисциплинарном характере работ.

Образ хаотичной корневой структуры, позаимствованный из постструктурализма, применим сразу на нескольких уровнях. Он позволяет характеризовать общие свойства системы, выделяя ее базисный принцип, а также используется при изучении ресурса или отдельного текста, циркулирующего внутри пространства социальных медиа и видоизменяющегося в ней. В этом случае объект рассматривается как нелинейная структура, во многом полиморфная и обрастающая новыми знаниями либо утрачивающая часть из них. Монолитный смысловой центр, характерный для традиционных средств массовой информации, трансформируется в исходную точку для интерпретации.

Соответствующие изменения согласуются с принципом «незначащего разрыва». «Мы не можем отдаться дуализму или дихотомии. Мы создаем разрыв, проводим линию ускользания, но всегда рискуем обнаружить на ней организации, рестратифицирующие совокупность, образования, возвращающие власть означающему, атрибуции, восстанавливающие субъект» [4].

Приведенная выше цитата из работы французских исследователей отличается высокой степенью метафоричности и отсылает скорее к сфере постмодернистского художественного творчества как отражению постструктуралистского мироощущения и миропонимания. Тем не менее с определенной долей условности ее можно применять и к текстам СМИ, описывающих социальные явления и процессы. Подобные тексты, получая популярность в пространстве социальных медиа и дополняясь комментариями и интерпретациями, способны отрываться как от каждого отдельного интерпретатора, так и от автора с первоисточником, какое-либо время функционируя автономно.

Субъект-объектные отношения в этом случае претерпевают значительные изменения: объект (текст) независимо от субъекта дополняется трактовочно-комментарийным комплексом, его семантическое ядро может как подкрепляться новыми фактами, так и терять свои очертания. В итоге изначально заданная атрибутивность ускользает, а текст становится связанным в разной степени сразу с несколькими субъектами и их отношениями, определяемыми как технологическими, так и идеологическими факторами. Ни один из субъектов при этом не оказывает решающего влияния на весь смысловой комплекс, как и на пути распространения текста, то есть не посягает на автономность как таковую. Возможность создания самодовлеющей сущности оказывается немаловажной при изучении взаимосвязи социальных медиа и постструктуралистской философской мысли. Вариативность и возможность элиминации части субъектов, кроме того, что является автором изначального текста, явственно коррелирует с принципом «незначащего разрыва».

Наиболее важным в контексте вышеизложенного становится выделение полисубъектного трактовочно-комментарийного комплекса, формирующего новый тип текста. Природа трактовочно-комментарийного комплекса дуалистична: с одной стороны, он органично связан с авторским текстом-первоисточником, с другой - автономен, отчужден от субъекта. 
Публичная сфера, виртуализация, ризома: коммуникативные практики социальных медиа Рунета

Напрашивается параллель с постмодернистской идеей «смерти автора», также нашедшей свое отражение в области художественного творчества. Самоочевидно, что речь в этом случае идет не об устранении авторского начала при анализе текстов внутри пространства социальных медиа, но о смещении акцентов и детальном изучении дополнительных семантических включений.

Полисубъектность трактовочно-комментарийного комплекса и ориентация на дополнение первоисточника также оказываются органично связаны с постструктуралистским мироощущением. Отечественный исследователь О.Ю. Цендровский пишет по этому поводу: «Постмодернизм выдвинул концепцию невозможности существования автономного, суверенного индивида и переосмыслил творчество как скрытую цитацию и рекомбинацию уже написанного» $[12$, с. 33].

Концепция рекомбинации текстов проявляется себя и в традиционных средствах массовой информации - например, как неизжитый «кризис вторичности», оказавшийся в центре внимания исследователей и практиков медиа во время массовизации электронных СМИ в Рунете. В пространстве социальных медиа поднятый вопрос приобретает амбивалентный характер. С одной стороны, социальные медиа в силу своей природы вступают в противоречие с представлениями о перманентном цитировании текстов, созданных по стандартам и шаблонам, присущим традиционным СМИ, с другой - неизбежно опираются на них, о чем мы писали выше.

С получившей широкое распространение в постмодернизме идеей «смерти автора» коррелирует концепция гипертекста. Последняя также сформулирована и довольно детально проработана в доинтернетовскую эпоху, однако максимально полно раскрывается именно в сетевом пространстве. Гипертекст одновременно становится необходимым условием существования для ризомной и во многом хаотичной структуры, но в некоторой степени ограничивает ее, придавая системе контуры, задавая иерархию, формируя семантическое единство разнородных на первый взгляд текстовых отрывков.

Представления о гипертексте появляются задолго до философских концепций пост- структуралистов. Так, гипертекст лежит в основе любого каталога, энциклопедии и иных текстовых форматов. При этом постструктуралисты определяют принцип гипертекстовости как фундамент работы с текстовыми фрагментами.

Структурирование разнообразных уровней обобщения, ставшее возможным благодаря технологии гиперссылок, широко применяется в социальных медиа, во многом предопределяя процесс распространения текста и его возможные интерпретации.

По мысли постструктуралистов, на смену последовательного мышления человека «галактики Гутенберга» [9] рано или поздно придет нелинейный способ организации текстового пространства, порывающий с догматизмом и трансформирующий когнитивные механизмы. Гипертекстовая природа Интернета стала благодатной почвой для воплощения этого теоретического положения. Гипертекст, ранее являвший себя в основном в области художественного творчества постмодернистов, на нынешнем этапе развития коммуникаций находит отражение как в текстах СМИ и в социальных медиа, так и в бытовом общении.

Такое явление, как гипертекстуализация, формирует обширный круг вопросов - от соблюдения авторских прав в Интернете до влияния нелинейных структур на мыслительные процессы.

Принципиальным отличием гипертекста в интернет-пространстве является то, что «связь между отдельными текстами осуществляется в единой среде, что позволяет читать текст не только на одном уровне, как на бумаге, но благодаря внутренним и внешним ссылкам просматривать его вглубь» [8, с. 25].

В контексте исследования гипертекста в интернет-пространстве, в частности в социальных медиа, нельзя обойти вниманием еще одну особенность постструктуралистского мироощущения, связанную с разработанностью игрового начала. Оно проявляется в том, что гипертекст зачастую только создает иллюзию бесконечного углубления знаний с помощью ссылок и процесса перманентного поиска ускользающей истины при увеличении текстового материала.

Двойственность этого процесса заключается в том, что у пользователя, с одной сто- 
роны, формируется представление о получении все большего количества информации об интересующем его объекте, укреплении связи между текстом и социальной реальностью. С другой стороны, возникает фрустрация от недостижимости поставленной цели на практике, способная отразиться на когнитивных процессах и приводящая к разочарованию и ощущению относительности истины, также характерному для постструктурализма. Образовывающиеся лакуны становятся идеальным вместилищем для различного рода слухов и догадок.

Отчасти описанное явление связано с неизжитостью «кризиса вторичности» и транслированием большого количества однотипных текстов на основе одного или нескольких первоисточников, однако в случае с социальными медиа немалую роль играют особенности самой коммуникативной площадки.

Следовательно, отношение к гипертексту в пространстве Интернета вообще и социальных медиа в частности тоже оказывается двойственным. Поэтому дальнейшее детальное исследование природы описываемого феномена и его влияния на функционирование текстов в обозначенной среде представляется как никогда актуальным.

Эмпирические исследования волгоградского сегмента социальных медиа, основанные на контент-анализе сообществ СМИ, пресс-служб, а также независимых пабликов, ориентированных на распространение социально значимого контента, максимально приближенного к журналистскому, позволяют говорить о том, что гиперссылки в первую очередь выполняют интегрирующую функцию, объединяя несколько групп, действующих на единой платформе (в нашем случае - в одной социальной сети). Цитирование в основном представлено следующим образом: тексты, подготовленные профессионалами сферы медиа, становятся объектом общественной экспертизы, то есть запускается механизм медиапросвещения.

В рамках данной работы остановимся подробнее на характеристиках гипертекста в коммуникативном пространстве социальных медиа. Здесь они предоставляют возможность определить первоисточник текста, проследить пути его трансформации и вписать в контекст того или иного ресурса, разметившего запись. Социальные медиа в этом плане представляют собой интертекстовое пространство открытой структуры с развитыми возможностями цитирования, в том числе с помощью репостов, которые вместе с другими механизмами цитирования и комментирования формируют единый семантический комплекс, отличающийся от исходного. Гипертекст в этом случае выступает как ядро, вокруг которого формируется трактовочно-комментарийный комплекс с его дополнительным означиванием.

Российский исследователь М.Г. Карымова пишет: «Гипертексты глобальной Сети являются скорее "надличными" созданиями постмодерной культуры, чем творениями автономных индивидов. Сама технология ссылок предполагает “множественность” авторов. Деперсонализация автора определяется перекрестной структурой гипертекста» [7, с. 68].

Внутри пространства социальных медиа Рунета симбиотически дополняют друг друга два направления - коллективно-общественное, суть которого отражена в приведенной выше цитате, и индивидуально-личностное, без которого невозможно создание текстовпервоисточников, а также появление сетевых лидеров мнений. Таким образом, постмодернистская «смерть автора» оказывается в изучаемом коммуникативном пространстве довольно условной.

Взаимопроникновение и взаимосвязь коллективно-общественного и индивидуальноличностного начал во многом определяют современный облик социальных медиа, где фрагментарность, характерная для дневниковых записей, сосуществует с интертекстовостью и перманентной ориентацией на шаблоны, используемые СМИ, а черты эпистолярного жанра, авторского по своей природе, - с постструктуралистской концепцией «смерти автора». Конвергентные и дивергентные силы, поддерживающие систему и одновременно придающие ей черты ризомы, дополняют друг друга. Некая парадоксальность и разнонаправленность паттернов активности в коммуникативном пространстве социальных медиа также иллюстрируют их глубокую связь с философской мыслью постструктурализма. Подобная эклектичность в некоторой степе- 
Публичная сфера, виртуализация, ризома: коммуникативные практики социальных медиа Рунета

ни затрудняет исследование феномена социальных медиа, однако не исключает полностью его познаваемости.

Затронутая тема сосуществования коллективно-общественного и индивидуальноличностного в пространстве социальных медиа приводит к вопросу об особенностях публичной сферы на представленной площадке. Наиболее полное отражение понятие публичной сферы и ее характеристики получили в работах немецкого философа Юргена Хабермаса, в частности в труде под названием «Структурное изменение публичной сферы. Исследования относительно категории буржуазного общества» [11]. Если в предыдущих и последующих частях представленного исследования акцент делается на взаимодействии социальных медиа с философией постструктурализма, то здесь мы имеем дело с одним из основателей критической теории, которая в этом случае явно испытывает влияние неомарксизма и иных течений.

Ю. Хабермас подразумевает под публичной сферой область ненасильственного диалога, имеющего своей целью установление консенсуса, принципиального взаимопонимания, основанного на разделении государства и общества, публичности и приватности. Публичная сфера создана частными индивидами, которые собираются вместе как общественность и артикулируют проблемы общества.

Коммерциализацию общественной жизни, наблюдавшуюся в ХХ в., Ю. Хабермас считает главной причиной кризиса публичной сферы. В этом плане его идеи во многом корреспондируют с постструктуралистской разочарованностью в традиционных социальных институтах. В этих условиях традиционные СМИ перестают отражать социальную действительность. Неспособность избежать редукционизма и сформировать рациональную модель публичной коммуникации Ю. Хабермас связывает как с самой капиталистической системой, так и с постмодернистской культурой, отличающейся релятивизмом. Итогом протекающих процессов становится недостаток в коммуникативной демократии.

Социальные медиа появляются во многом как реакция на общую разочарованность в возможностях традиционных СМИ. Представляя собой инструмент гражданской жур- налистики и активатор медиапросвещения, они реконструируют - со значительными оговорками - публичную сферу. На данном этапе развития социальных медиа в них сформирована дихотомия «государство - общество», которая, согласно Ю. Хабермасу, служит показателем реальной, а не мнимой публичной сферы. Тем не менее явная тенденция к увеличению контроля за этой коммуникативной системой, а также все большая активность в ней представителей экономических организаций и формальных социальных институтов говорит о том, что в будущем публичную сферу в социальных медиа ждут серьезные трансформации.

Ю. Хабермас отмечает, что основа публичной сферы - это различия между реальным положением дел и представлениями о должном социальном устройстве. В силу своей природы она обладает высокими критическим потенциалом. Такое положение обусловливает, во-первых, активацию гражданской активности, во-вторых, стремление властей контролировать эту активность с помощью законодательных мер различной степени жесткости.

Система социальных медиа Рунета на данном этапе своего развития обладает несколькими характерными признаками пространства публичной сферы. Во-первых, она представляется пространством для распространения тех идей, которые считают наиболее актуальными сами пользователи, а не модераторы внутри системы СМИ. Во-вторых, здесь представлен широкий спектр интерпретаций обсуждаемого. В-третьих, она испытывает не такое сильное влияние коммерческих структур, хотя последние тенденции говорят о все большем присутствии экономических организаций в социальных медиа. Наконец, активность в социальных медиа способна выходить за сетевые пределы.

Одновременно сразу несколько признаков публичной сферы свидетельствуют о том, что в социальных медиа она не проявляет себя в своем классическом варианте. Так, это неразделенность публичности и приватности, вовлечение в коммуникативное пространство представителей формальных социальных институтов, отсутствие четкого дробления между общественным и государственным. Кро- 
ме того, дискуссии в социальных сетях направлены скорее на презентацию тех или иных взглядов, но не на достижение консенсуса.

В контексте исследования взаимосвязи современной философской мысли и социальных медиа Рунета возникает необходимость исследовать феномен виртуальности. В широком смысле он заключается в ориентации не на факты действительности (постструктурализм выдвигает тезис о ее социальной конструируемости и, следовательно, относительности), а на их имиджевую составляющую.

Постоянно увеличивающийся разрыв между означающим и означаемым нашел свое отражение в трудах таких западных философов, как Т. Адорно, Г. Маркузе, Ж. Деррида. Наиболее глубокую характеристику ему дал французский философ Ж. Бодрийяр, выдвинувший теорию симулякров.

Особенно остро вопрос о виртуальности сетевого пространства стоял на заре распространения интернет-технологий и перед их окончательной массовизацией. В 2000 г. российский исследователь Д.В. Иванов пишет: «Приоритетным в последние годы XX в. стало развитие не информационных, а симуляционных технологий виртуальной реальности. Возникают не только качественно новые формы передачии обработки данных, но в первую очередь достигается все большее сходство между работой на компьютере и управлением реальными объектами, а также сходство коммуникаций в режиме online с общением в реальном пространстве-времени» [6, с. 38].

Виртуализация в сетевом пространстве связана как с технологическими, так и с философскими аспектами, на сложную взаимосвязь которых мы указывали выше. Описанный в трудах постструктуралистов феномен раскрывает себя в эпоху тотальной компьютеризации и в итоге находит свое отражение даже на бытовом уровне. «В этой перспективе появляется возможность трактовать общественные изменения, различая старый и новый типы социальной организации с помощью дихотомии “реальное / виртуальное"» [6, с. 38].

Что касается виртуальности в социальных медиа Рунета, то она ярко проявляет себя с самых ранних этапов становления изучаемой системы. «Исторически сложилось так, что виртуальные персонажи играли несколько иную роль в русском Интернете, чем в Интернете англоязычном» [2]. Отчасти это связано с некоторым отставанием распространения интернет-технологий в России и их последующей форсированной массификацией. Ориентация на постмодернистское миропонимание и мироощущение к этому времени широко распространилась как среди компьютерщиков, так и среди рядовых пользователей. Феномен виртуализации индоктринирован в сознание последних с помощью произведений массовой культуры, которые неизбежно упрощают его, но одновременно создают иллюзию осведомленности.

Как было обозначено выше, и традиционные средства массовой информации, и социальные медиа по своей природе тяготеют к виртуальности, не только и не столько отражая факты окружающей реальности, сколько формируя единую картину мира, образ, который лишь отчасти совпадает с действительным положением дел. Новозеландский ученый Л. Гуд пишет по этому поводу: «Можно оставить в стороне носящие чисто философский характер дебаты на тему объективности. Главное - не замалчивать события и не умалять их значимость, ведь в противном случае проблемы и идеи останутся неизвестными для читателя. Указанный аспект, однако, невозможно отделить от влияния на общественное мнение, интерпретации и ретрансляции» [13].

Социальные медиа Рунета связаны с кризисом доверия к традиционным средствам массовой информации, потребностью в альтернативных источниках информации, во многом создаваемой самими пользователями. В то же время своей знаково-символической природой они схожи со СМИ, а происходящие внутри этого коммуникативного пространства процессы целесообразно обозначить как символические.

Кроме того, в социальных медиа в процессе эволюции и изменений, связанных с рядом факторов внешнего и внутреннего порядка, увеличивается влияние медийного дискурca, что вписывается в концепцию общей медиатизации публичного пространства. Постоянно нарастающее присутствие политических акторов, представителей общественных организаций различного типа и экономических 
Публичная сфера, виртуализация, ризома: коммуникативные практики социальных медиа Рунета

структур увеличивает число имиджевых символов, насыщая среду социальных медиа симулякрами.

Изначально склонное к различным формам виртуализации медийное пространство дополняется иными элементами, связанными с виртуализацией политической, экономической, социальной и культурной сфер, которые долгое время обозначались как «реальные». Именно постструктуралисты выдвигают теоретические обоснования их относительности, в то время как сетевое пространство подкрепляет эти тезисы практикой.

Увеличение имиджевых символов и замена информации ее трактовками в своем пределе способны привести к замене репрезентации симуляцией. Об угрозе подобной виртуализации пишет Ж. Бодрийяр: «Репрезентация исходит из принципа эквивалентности знака и реального. Симуляция, наоборот, исходит из утопичности принципа эквивалентности, из радикальной негации знака как ценности, из знака как реверсии и умерщвления всякой референции» [1].

Двойственность социальных медиа сопряжена с двумя тенденциями, причем обе связаны с постструктуралистскими миропониманием и мироощущением. Во-первых, это кризис доверия к традиционным социальным институтам, в том числе к СМИ; во-вторых, сомнение в принципе эквивалентности между отображаемым и отображенным, представление об относительности истины. Социальные медиа, следовательно, одновременно являют собой и порождение виртуальной среды, и реакцию, зачастую довольно критическую, на эту среду. Эта двойственность представляется симптоматичной в контексте изучения взаимосвязи социальных медиа и философии постструктурализма.

В перспективе виртуализация социальных медиа, их дистанцирование по отношению к фактам действительности в пользу определенных трактовок, имеющих идеологическую окраску, могут сказаться на доверии к данному источнику информации. В этом случае пользователь рискует рассматривать социальные медиа как пространство для функционирования симуляционных моделей, отличных от представленных в СМИ только интерпретациями, но не природой. «Факты больше не имеют собственной траектории, они рождаются на пересечении моделей, один и тот же факт может быть порожден всеми моделями одновременно» [1].

Излишний релятивизм, в целом характерный для постструктуралистского мироощущения, при этом начинает претендовать на тотальность. Вкупе с общей установкой на нарративизацию наблюдается тенденция отрыва от информационных поводов в пользу виртуальных конструктов. Таково доведенное до своего предела представление о глобальной виртуализации в Рунете, в частности в социальных медиа. В этом случае отображенное становится чем-то автономным и более значимым, нежели отображаемое.

Поднятая проблема актуальна не только для социальных медиа или традиционных средств массовой информации, она в той или иной степени проявляется во всех сферах общественной жизни. Однако в представленном исследовании она приобретает особую значимость, ведь социальные медиа на данном этапе своего развития воспринимаются как альтернатива «преломлению» реальности в отражении СМИ.

Пессимистический сценарий развития новой коммуникативной площадки во многом связан с постструктурализмом, он вписывает социальные медиа в систему виртуализированного пространства, их коннотации инаковости оказываются чисто формальными. Подобные суждения внутренне непротиворечивы, но не исключают и альтернативных вариантов развития событий, также имеющих право на существование.

Противоположная тенденция связана с тем, что виртуальные сообщества, зародившиеся в социальных медиа, не только закрепляют установившиеся связи, но и создают новые общности, вплоть до институционализированных. Особенно активны в этом отношении представители действующих политических сил, коммерческих структур и общественных организаций, стремящихся расширить свои ряды. Сетевая активность в этом случае не становится вещью в себе, она потенциально коррелирует с иными видами активности, напрямую связанными с социальной реальностью. Социальные медиа как порождение виртуальной среды способны пре- 
одолевать ее, выводя пользователей на новый уровень общности.

Так, например, сообщества, образовавшиеся на основе некоторых пабликов в социальной сети «ВКонтакте», ориентированных на освещение событий в Волгоградской области, выполняют не только рекреативные, но и социальные функции, например, участвуют в благотворительных акциях.

Таким образом, подход, фокусирующий внимание исключительно на виртуализации сфер общественной жизни в пространстве социальных медиа, представляется хоть и логически непротиворечивым, но несколько упрощающим протекающие коммуникативные процессы. Рассматриваемое явление носит более сложный и комплексный характер: реальность не только виртуализируется в сетевом пространстве, но и получает свое осмысление на практическом уровне, который вносит коррективы в теоретические конструкты, разработанные в доинтернетовский период.

Виртуальное и реальное сосуществуют внутри системы разнонаправленных взаимодействий. Социальные медиа, способные как виртуализировать определенные социальные действия, так и стимулировать обратный процесс, являются наглядной иллюстрацией взаимодействий такого рода.

Подводя итог, отметим, что в этом случае также нецелесообразно заострять внимание на одностороннем влиянии. Действительно, целый ряд характеристик социальных медиа и процессов, протекающих в них, получают толкование в трудах постструктуралистов, следовательно, изучение их работ - необходимый этап при исследовании новых коммуникативных практик. Тем не менее некоторые черты социальных медиа укладываются в постструктуралистские философские концепции лишь с определенными допущениями либо вовсе им противоречат.

Изучение данного феномена исключает линейный подход, когда каждому явлению в социальных медиа следует дать постструктуралистское толкование. Столь же нецелесообразными будут попытки представить социальные медиа как нечто не зависящее от социального контекста в целом и ведущих философских концепций современности в частности.
Пройдя этап своего становления, социальные медиа должны изучаться как феномен, функционирующий за счет оснований внутреннего порядка; вместе с тем он естественно соприкасается с целым рядом иных разнородных феноменов, среди которых в зависимости от степени взаимовлияния можно условно выделить «корневые» и «периферийные». Одной из таких «корневых» систем для социальных медиа являются философские концепции, в первую очередь постструктуралистские. Комплексное изучение как можно большего числа структур, влияющих на коммуникативные практики в социальных медиа, способно дать максимально объективные представления об изучаемом объекте.

\section{СПИСОК ЛИТЕРАТУРЫ}

1. Бодрийяр, Ж. Симулякры и симуляция / Ж. Бодрийяр. - Электрон. текстовые дан. - Режим доступа: http://lit.lib.ru/k/kachalow_a/simulacres_ et_simulation.shtml. - Загл. с экрана.

2. Горный, Е. А. Виртуальная личность как жанр творчества / Е. А. Горный // Сетевая словесность. Электрон. текстовые дан. - Режим доступа: http:// www.netslova.ru/gorny/vl.html. - Загл. с экрана.

3. Громыко, Н. В. Интернет и постмодернизм - их значение для современного образования / Н. В. Громыко // Вопросы философии. - 2002. № 2. - С. 176-190.

4. Делез, Ж. Капитализм и шизофрения. В 2 кн. Кн. 2. Тысяча плато / Ж. Делез, Ф. Гваттари. - Электрон. текстовые дан. - Режим доступа: https://litresp.ru/chitat/ru/\%D0\%94/delez-zhilj/ kapitalizm-i-shizofreniya-kniga-2-tisyacha-plato/2.Загл. с экрана.

5. Емелин, В. А. Ризома и Интернет/ В.А. Емелин. - Электрон. текстовые дан. - Режим доступа: http://emeline.narod.ru/rhizome.htm. - Загл. с экрана.

6. Иванов, Д. В. Виртуализация общества / Д. В. Иванов - СПб. : Петербург. Востоковедение, 2000. $-96 \mathrm{c}$.

7. Карымова, М. Г. Гипертекст в философии постмодернизма / М. Г. Карымова // Вестник Тюменского государственного университета. - 2002. № 1. - С . 64-69.

8. Лукина, М. М. СМИ в пространстве Интернета / М. М. Лукина, И. Д. Фомичева. - М. : Изд-во фак. журналистики МГУ, 2005. - 89 с. - (Серия «Интернет-журналистика» ; вып. 1).

9. Маклюэн, М. Галактика Гутенберга. Становление человека печатающего / М. Маклюэн. М. : Акад. проект : Фонд «Мир», 2005. - 496 с. 
Публичная сфера, виртуализация, ризома: коммуникативные практики социальных медиа Рунета

10. Философский словарь / отв. ред. И. Т. Фролов. - М. : Республика, 2001. -719 с.

11. Хабермас, Ю. Структурное изменение публичной сферы. Исследования относительно категории буржуазного общества / Ю. Хабермас. - М. : Весь мир, 2016. - 334 с.

12. Цендровский, О. Ю. Культурно-мировоззренческие основания глобального сетевого общества XXI века/О.Ю.Цендровский//Человек и культура. - 2015. №5-C. 1-57.-DOI: 10.7256/2409-8744.2015.5.16316.

13. Goode, L. Social news, citizen journalism and democracy / L. Goode. - Electronic text data. - Mode of access: http://nms.sagepub.com/content/11/8/ 1287.abstract. - Title from screen.

\section{REFERENCES}

1. Baudrillard J. Simulyakry i simulyatsiya [Simulacra and Simulation]. URL: http://lit.lib.ru/k/ kachalow_a/simulacres_et_simulation.shtml (accessed 12 November 2018).

2. Gornyy E.A. Virtualnaya lichnost kak zhanr tvorchestva [Virtual Personality as a Genre of Art]. Setevaya slovesnost, 2007. URL: http://www.netslova. ru/gorny/vl.html (accessed 12 November 2018).

3. Gromyko N.V. Internet i postmodernizm - ikh znachenie dlya sovremennogo obrazovaniya [Internet and Postmodernism: Their Importance for Modern Education]. Voprosy filosofii, 2002, no. 2, pp. 176-190.

4. Deleuze G., Guattari P. Kapitalizm $i$ shizofreniya. V2 kn. Kn. 2. Tysyacha plato [Capitalism and Schizophrenia. In 2 Books. Book. 1. Thousand Plateaus]. URL: https://litresp.ru/chitat/ru/\%D0\%94/ delez-zhilj/kapitalizm-i-shizofreniya-kniga-2-tisyachaplato/2 (accessed 12 November 2018).
5. Emelin V.A. Rizoma i Internet [Rhizome and Internet]. URL: http://emeline.narod.ru/rhizome.htm (accessed 12 November 2018).

6. Ivanov D.V. Virtualizatsiya obshchestva [Virtualization of Society]. Saint Petersburg, Peterburg. vostokovedenie Publ., 2000. 96 p.

7. Karymova M.G. Gipertekst v filosofii postmodernizma [Hypertext in Postmodern Philosophy]. Vestnik Tyumenskogo gosudarstvennogo universiteta, 2002, no. 1, pp. 64-69.

8. Lukina M.M., Fomicheva I.D. SMI v prostranstve Interneta [Media in the Internet Space]. Moscow, Izd-vo fak. zhurnalistiki MGU, 2005. 89 p. (Seriya 'Internet-zhurnalistika'; iss 1).

9. McLuhan M. Galaktika Gutenberga. Stanovlenie cheloveka pechatayushchego [The Gutenberg Galaxy: The Making of Typographic Man]. Moscow, Mir Publ., 2005. 496 p.

10. Frolov I.T. Filosofskiy slovar [Philosophical Dictionary]. Moscow, Respublika Publ., 2001. $719 \mathrm{p}$.

11. Habermas J. Strukturnoe izmenenie publichnoy sfery. Issledovaniya otnositelno kategorii burzhuaznogo obshchestva [The Structural Transformation of the Public Sphere: an Inquiry into a Category of Bourgeois Society]. Moscow, Ves mir Publ., 2016. $334 \mathrm{p}$.

12. Tsendrovskiy O.Yu. Kulturnomirovozzrencheskie osnovaniya globalnogo setevogo obshchestva XXI veka [Cultural and Ideological Foundations of the Global Network Society of the $21^{\text {st }}$ Century]. Chelovek i kultura, 2015, no. 5, pp. 157.DOI: 10.7256/2409-8744.2015.5.16316.

13. Goode L. Social news, citizen journalism and democracy. URL: http://nms.sagepub.com/content/11/ 8/1287.abstract (accessed 12 November 2018).

\section{Information about the Authors}

Aleksandr V. Mlechko, Doctor of Philology, Professor, Department of Russian Philology and Journalism, Volgograd State University, Prosp. Universitetsky, 100, 400062 Volgograd, Russian Federation, mlechko@mail.ru.

Ivan N. Shamaev, Postgraduate Student, Department of Journalism and Media Communications, Volgograd State University, Prosp. Universitetsky, 100, 400062 Volgograd, Russian Federation, vonschwarz@mail.ru.

Olga N. Didenko, Ph.D. in Philosophy, Associate Professor at the Department of Philosophy, Volgograd State University, Prosp. Universitetsky, 100, 400062 Volgograd, Russian Federation, didenko@volsu.ru.

Olesja A. Kozlova, Candidate of Philology, Associate Professor of the Department of Russian Philology and Journalism, Volgograd State University, Prosp. Universitetsky, 100, 400062 Volgograd, Russian Federation, olesya-kozlova@mail.ru. 


\section{Информация об авторах}

Александр Владимирович Млечко, доктор филологических наук, профессор кафедры русской филологии и журналистики, Волгоградский государственный университет, просп. Университетский, 100, 400062 г. Волгоград, Российская Федерация, mlechko@mail.ru.

Иван Николаевич Шамаев, аспирант кафедры русской филологии и журналистики, Волгоградский государственный университет, просп. Университетский, 100, 400062 г. Волгоград, Российская Федерация, vonschwarz@mail.ru.

Ольга Николаевна Диденко, кандидат философских наук, доцент кафедры философии, Волгоградский государственный университет, просп. Университетский, 100, 400062 г. Волгоград, Российская Федерация, didenko@volsu.ru.

Олеся Александровна Козлова, кандидат филологических наук, доцент кафедры русской филологии и журналистики, Волгоградский государственный университет, просп. Университетский, 100, 400062 г. Волгоград, Российская Федерация, olesya-kozlova@mail.ru. 